\title{
ОСОБЛИВОСТІ НАДАННЯ ПАЛІАТИВНОЇ ДОПОМОГИ ХВОРИМ НА ВІЛ/СНІД В ОДЕСЬКОМУ ОБЛАСНОМУ ЦЕНТРІ СОЦІАЛЬНО ЗНАЧУЩИХ ХВОРОБ
}

\author{
А. О. Боб ${ }^{1}$, О. О. Чукур ${ }^{1}$, Н. О. Єрмакова ${ }^{2}$, А. В. Гуцол ${ }^{3}$ \\ ${ }^{1}$ Тернопільський національний медичний університет \\ імені І. Я. Горбачевського МОЗ Украӥни \\ ${ }^{2}$ Комунальне некомерційне підприємство “Одеський обласний иентр \\ соціально значущих хвороб» Одеської обласної ради \\ ${ }^{3}$ Одеське обласне базове медичне училище
}

Сестринський персонал відіграє ключову роль в організації паліативної допомоги хворим на ВІЛ/СНІД. Паліативна допомога є цілісним підходом, що складається з медичного, соціального, психологічного та духовного компонентів. Медсестра - ключова особа в оточенні пацієнта, яка забезпечує належну медичну допомогу, кваліфікований догляд та психологічну підтримку паліативним пацієнтам.

\section{PECULIARITIES OF PALLIATIVE CARE FOR HIV/AIDS PATIENTS AT ODESA REGIONAL CENTER OF SOCIALLY IMPORTANT DISEASES}

\author{
A. O. Bob' ${ }^{1}$ O. O. Chukur ${ }^{1}$, N. O. Ermakova ${ }^{2}$, A. V. Hutsol ${ }^{3}$ \\ ${ }^{1}$ I. Horbachevsky Ternopil National Medical University \\ ${ }^{2}$ Communal nonprofit enterprise "Odesa Regional Center for Socially Important Diseases" \\ of the Odesa Regional Council \\ ${ }^{3}$ Odesa Basic Medical College
}

Nursing staff play a key role in the organization of palliative care for people living with HIV/AIDS and tuberculosis. Palliative care is a holistic approach, consisting of a medical, social, psychological and spiritual component. A nurse is the key person in the environment of the patient who provides proper medical care, qualifi ed assessment and psychological support to palliative patients.

Вступ. Сучасна медико-демографічна ситуація в Україні, як і в цілому світі, характеризується зменшенням загальної чисельності, значним постарінням населення, зростанням рівнів захворюваності та смертності від тяжких хронічних та інфекційних захворювань з чіткою тенденцією до збільшення в майбутньому. За даними дУ «Український центр контролю за соціально небезпечними хворобами Міністерства охорони здоров'я України», у 14 регіонах нашої держави, у тому числі в Одеській області, спостерігають підвищення регіональних показників смертності від СНІДу порівняно з відповідними показниками минулого року [1]. Протидія ВІЛ-інфекції/ СНІДу залишається одним із пріоритетних завдань держави. Незважаючи на зниження інтенсивності епідемічного процесу ВІЛ-інфекції, зросли ризики

(ㄱ А. О. Боб, О. О. Чукур, Н. О. Єрмакова, А. В. Гуцол, 2020 щодо поширення ВІЛ в умовах гуманітарної кризи та бойових дій на сході України.

Україна сьогодні посідає одне з перших місць серед країн європейського регіону за кількістю ВІЛ-позитивних осіб. За даними, на початку 2019 р. в країні проживало 244000 ВІЛ-позитивних людей. Кожен сотий громадянин України у віці 15-49 років інфікований ВІЛ, що є одним із найвищих показників серед країн регіону. За даними Європейського центру з контролю та профілактики захворюваності та Європейського регіонального бюро Всесвітньої організації охорони здоров'я, регіон Східної Європи та Центральної Азії, до якого територіально належить Україна, єдиний у світі, де продовжує зростати кількість нових випадків ВІЛ-інфекції та смертей від СНІДу [2].

Епідемія ВІЛ-інфекції в Україні на сучасному етапі характеризується переважним ураженням осіб 
працездатного віку зі зростанням частки вікової групи старше 50 років серед нових випадків захворювання. Протягом 2019 р. в Україні щодня реєстрували 50 випадків захворювання на ВІЛ-інфекцію, 24 - на СНІД і 9 випадків смерті від хвороб, зумовлених СНІДом. Згідно з офіційними статистичними даними за період 1987 - травень 2019 р., у країні офіційно зареєстровано 341084 випадки ВІЛ-інфекції серед громадян України, зокрема 114487 випадків захворювання на СНІД і 49751 випадок смерті від захворювань, зумовлених СНІДом.

Основна частина. Нормативними документами м03 України передбачено, що паліативна допомога (ПД) пацієнтам, хворим на туберкульоз та ВІЛ-інфекцію/СНІД, надається у відповідних спеціалізованих лікувально-профілактичних закладах [6-8]. Одеський обласний центр соціально значущих хвороб створений у березні 2018 р. в результаті об'єднання обласної протитуберкульозної служби і центра з профілактики та боротьби зі СНІДом. Центр розрахований на 720 ліжок (2 поліклінічних та 9 стаціо-

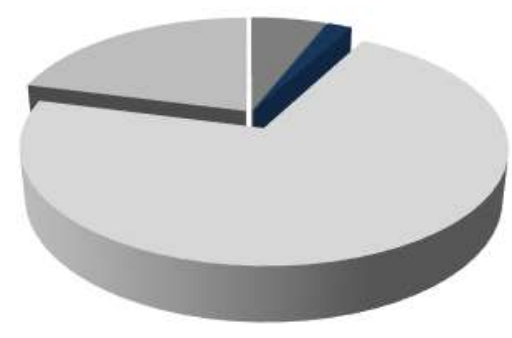

Puc. 1. Основні шляхи передачі ВІЛ по Україні за 2019 р.

Захворюваність на СНІД за останні 3 роки залишалась на стабільному рівні (2017 р. - 60,0; 2018 р. - 71,8; за 9 місяців 2019 р. - 53,0 на 100000 населення) та перевищувала у 3 рази середньоукраїнські показники. Аналіз захворюваності на СНІД показав, що основною причиною виявлення хворих на пізній стадії ВІЛ-інфекції залишається несвоєчасне звернення пацієнтів до медичних закладів.

За результатами 2017-2019 рр. спостерігали позитивну тенденцію щодо збільшення ВІЛ-позитивних осіб, взятих під медичний нагляд. у 2018-2019 рр. показник диспансеризації збільшився на 17 \% порівняно з 2017 р. (взято під медичний нагляд у 2017 р. - 2157 осіб; в 2018 р. - 2699 осіб та за 11 місяців 2019 р. - 2351 особа) та становив у 2018 р. - 90,9 \%; за 9 місяців 2019 р. - 83,8 \% (проти 73,1 \% - в 2017 р.). Це зумовлено змінами, які відбулись протягом звітного періоду в сфері тестування на ВІЛ та залучення нарних відділень). Паліативне відділення, яке розташоване в місті Білгород-Дністровський Одеської області, розраховане на 80 ліжок. На сьогодні під медичним наглядом в Одеській області перебуває 22138 ВіЛ-інфікованих осіб, з них - 8402 пацієнта $з$ діагнозом СНІД.

Найбільшу поширеність на ВІЛ зареєстровано у м. Одеса (1 279,1), Чорноморськ (1 018,0), Березівському $(1087,9)$, Лиманському $(1096,5)$, Роздільнянському $(933,3)$ та Захарівському $(970,4)$ районах області.

Показники захворюваності на ВІЛ склали у 2017 р. 90,7; в 2018 р. - 113,6 та за 9 місяців 2019 р. - 74,2 на 100000 населення та перевищували середні по країні майже в 3 рази. Більшість випадків ВІЛ-інфекції реєстрували серед міського населення області (66 \%). У віковій структурі нових випадків ВІЛ-інфекції переважають особи віком 30-39 років (32,1 \%) та 15-24 років (20,1 \%). Домінуючим шляхом передачі ВІЛ-інфекції серед інших можливих (рис. 1) у 2019 р. залишився незахищений секс, який становить близько 73 \%.

\section{6\% Від матері до дитини \\ 2\% Статевий/гомосексуальний \\ 71\% Статевий/ гетеросексуальний \\ 21\% Через кров}

пацієнтів під медичний нагляд. Так, у 2018 р. було оптимізовано маршрут крові для проведення скринінгового тестування на ВІЛ (виключені з маршруту міжрайонні вірусологічні лабораторії та забезпечена своєчасна доставка зразків крові з усіх районів області безпосередньо в ЦІВЛ), що прискорило отримання результатів з 1,5-2 місяців до 2-3 днів. Одночасно в 2018-2019 рр. широко впроваджували тестування на ВІЛ із використанням двох швидких тестів на всіх рівнях надання медичної допомоги, що дало змогу лікарям у найкоротші терміни залучити ВІЛ-позитивних осіб до спеціалізованої медичної допомоги та призначення антиретровірусної терапії (АРТ). Впровадження швидких тестів на території області здійснювали за допомогою коштів міжнародного донора PEPFAR та БФ «Фундація АНТИСНІД-Україна». Позитивною практикою для області стала закупівля експрес-тестів для прискореної діагностики ВІЛ лікувально-про- 
філактичними закладами м. Южного, Савранського, Саратського, Татарбунарського, Ширяївського, Кілійського, Ізмаїльського, Михайлівського, Біляївського, Тарутинського районів тощо. В рамках реалізації Міської цільової програми протидії ВІЛ-інфекції/СНІДу, туберкульозу, гепатитам та наркоманії в місті Одеса «Прискорена відповідь Одеса» («Fast-Track Одеса») на 2018-2020 рр., прийнятої на сесії Одеської міської ради 06.06.2018 р. зі змінами від 19.09.2018 р., забезпечено фінансування закупівлі швидких тестів за рахунок місцевого бюджету.

У 2018-2019 рр. спостерігали щорічне збільшення осіб, протестованих на ВІЛ із використанням швидких тестів, на 11 \% (2016 р. - 46557 осіб; 2017 р. 51727 осіб; за 9 місяців 2018 р. - 51632 особи). У період 2017-2019 рр. охоплення населення області тестуванням на ВІЛ перевищувало 5 \% від кількості загального населення області (2017 р. - 7,2 \%; 2018 р. 6,7 \%; за 9 місяців 2019 р. - 5,4%). На цьому фоні спостерігали щорічне зменшення загальної кількості осіб, обстежених на ВІЛ, приблизно на 7 \% (2017р. 171336 осіб; 2018 р. - 158810 осіб; за 9 місяців 2019 р. - 127444 осіб), що пов'язано зі зменшенням обстеження таких обов'язкових для тестування на ВІЛ груп осіб як донори крові та вагітні жінки. В 20182019 рр. відзначали позитивну тенденцію щодо зростання обстеження представників груп ризику (35,8 \% - у 2018 р. та 34,3 \% - за 9 місяців 2019 р. проти 27,3 \% - в 2016 р.), серед яких найбільше споживачів ін'єкційних наркотичних речовин.

3 метою покращення роботи з надання медичної допомоги людям, які живуть з ВІЛ, розроблено та затверджено обласним наказом № 288 від 07.07.2018 р. «Локальний протокол надання медичної допомоги ВІЛ-інфікованим та хворим на СНІД дорослим та підліткам». Відповідні Локальні протоколи розроблені у кожному лікувально-профілактичному закладі первинного та вторинного рівнів області. У 2018-2019 рр. в області зареєстровано 6619 нових випадків захворюваності на ВІЛ-інфекцію, в тому числі 4393 випадки захворюваності на СНІД. Серед осіб, які захворіли на СНІД, близько 65 \% - це хворі на ко-інфекцію ТБ/ВІЛ. Також ко-інфекція ТБ/ВІЛ $є$ основною причи-

\section{СПИСОК ЛІТЕРАТУРИ}

1. Курницька Г. М. Стратегія розвитку паліативної допомоги в Україні на період до 2027 року / Г. М. Курницька // Медсестринство. - 2018. - № 2. - С. 42-45. ною смерті ВІЛ-інфікованих осіб та складає майже 60 \% від загальної кількості померлих від СНІДу.

Це обґрунтовує доцільність створення єдиного обласного центру соціально значущих хвороб, на базі якого пацієнти даної категорії отримують ефективне лікування поєднаної інфекції з дотриманням протиепідемічних вимог. Одночасно всі фахівці центру пройшли підготовку із ведення хворих на ко-інфекцію ТБ/ВІЛ та на сьогодні надають повний комплекс медичних послуг даній категорії пацієнтів (від обстеження на ВІЛ до призначення АРТ).

Застосування комбінованої антибіотикотерапії та високоактивної АРТ в останні роки дозволило значно покращити стан хворих та уповільнити прогресування хвороби, однак таке лікування не здатне повністю вилікувати і викликає цілий ряд побічних ефектів [4]. Надання ПД таким хворим зазвичай може супроводжуватися низкою труднощів як медичних (численні інфекції, тривале виснажливе лікування), так і психологічних, соціальних (важко доступні соціальні прошарки, часто - ВІЛ-інфіковані статеві партнери, близькі родичі, стигматизація й дискримінація, конфіденційність, великі втрати, страх перед хворобою) Міжнародна асоціація лікарів з проблем ВІЛ/СНІДу серед учасників паліативної допомоги хворим на ВІЛ/СНІД та туберкульоз вказують на першому місці роль медичних сестер, що є абсолютно закономірним [5]. Медсестра - ключова особа в оточенні пацієнта, яка забезпечує належну медичну допомогу, кваліфікований догляд та психологічну підтримку під час надання ПД.

Висновки. Забезпечення ПД високої якості пацієнтам із хронічними інфекційними захворюваннями, у тому числі ВІЛ-інфекцією/СНІДом, туберкульозом, повинно бути одним з пріоритетних напрямів розвитку української системи охорони здоров'я. Паліативна допомога ВІЛ-інфікованим хворим є складним медикосоціальним процесом, який вимагає сучасних медичних знань, нормативно-правового регулювання, соціальної та спеціальної підготовки молодших медичних спеціалістів на додипломному та післядипломному рівнях, що ґрунтується на розробці та використанні сучасного науково-методичного забезпечення.

2. Вильчинская Т. В. Паллиативная и хосписная помощь: сходство и различия / Т. В. Вильчинская, К. И. Бурлак // Therapia. Український медичний вісник. - 2017. № 7-8. - C. 42-44. 
3. Воліков І. Паліативна допомога пацієнтам з ВІЛ: робота мультидисциплінарної команди / І. Воліков // Управління закладом охорони здоров'я. - 2016. № 12. - С. 35-45.

4. Стан, проблеми і перспективи впровадження «Національної стратегії розвитку системи паліативної допомоги в Україні до 2022 року» / В. М. Князевич, А. В. Царенко, І. В. Яковенко, О. П. Брацюнь // Часопис «Фітотерапія». 2013. - № 4. - C. 4-7.

5. White Paper on standards and norms for hospice and pallianive care in Europe [Electronic resource] / Recommendations from the European Association for Palliative Care. Part I // European Journal of Palliative Care. 2009. - No. 16 (6). -177 P.278-289.

6. Про протидію поширенню хвороб, зумовлених вірусом імунодефіциту людини (ВІЛ), та правовий і со- ціальний захист людей, які живуть з ВІЛ : Закон України від 12 грудня 1991 року № 1972-XII [Електронний ресурс]. - Режим доступу : https://zakon.rada.gov.ua/laws/ show/1972-12.

7. Про затвердження клінічного протоколу надання паліативної допомоги, симптоматичної та патогенетичної терапії хворим на ВІЛ-інфекцію/СНІД : наказ МОЗ України від 03.07.2007 р. № 368 [Електронний ресурс]. Режим доступу : http://www.zakon.rada.gov.ua.

8. Про затвердження загальнодержавної цільової соціальної програми протидії ВІЛ-інфекції/СНІДу на 2014-2018 роки: Закон України від 20.10.2014 р. №1708-VII [Електронний ресурс]. - Режим доступу : http:// www.zakon.rada.gov.ua. 